\title{
Analysis of a historical landslide in the Rječina River Valley, Croatia
}

\author{
Sanja Dugonjić Jovančević*, Josip Peranić, Igor Ružić and Željko Arbanas
}

\begin{abstract}
Background: Large landslides triggered by rainfall and floods were registered on both sides of the Rječina River Valley, near City of Rijeka, in Croatia, where numerous instability phenomena in the past 250 years have been recorded, and yet only some locations have been investigated. The paper presents investigation of the dormant landslide located on the south-western slope, recorded in numerous historical descriptions from 1870. Due to intense and long-term rainfall, the landslide was reactivated in 1885, destroying and damaging houses in the eastern part of the Grohovo Village.

Results: 2D stability back analyses have been performed based on landslide features, in order to approximate the position of the sliding surface and landslide dimensions. Because of the very steep landslide topography and the slope covered by unstable debris material, a Remotely Piloted Aircraft System (RPAS) was used to provide the data about the present slope topography. The landslide 3D point cloud was derived using Structure-from-Motion (SfM) photogrammetry. In order to verify the cloud of georeferenced sliding points obtained from images, it was compared with the existing models acquired from terrestrial photogrammetry and laser scanning, showing good accordance and small changes through the years. Based on the classification and Uniaxial Compressive Strength test results, rock mass strength was defined using generalised Hoek-Brown's failure criteria.

Conclusions: Stability analysis results of the present slope conditions show that the slope is marginally stable for dry conditions, and that the critical seismic coefficient of about 0.14 would generate inertial forces corresponding to the factor of safety equal to 1 . Analyses were performed with the purpose to predict the possible reactivation of a dormant landslide, and the presented results could be used in the establishment of an early warning system.
\end{abstract}

Keywords: Dormant landslide, Flysch, Remotely Piloted Aircraft System, Structure-from-Motion photogrammetry, Rječina River Valley

\section{Background}

The Rječina River, Croatia, is a typical karstic river $18.7 \mathrm{~km}$ long, originating from the Gorski Kotar Mountains. The bottom of the Valley is 150 to $200 \mathrm{~m}$ above the sea level, while the highest peaks are at elevation $432 \mathrm{~m}$ in the south western and $412 \mathrm{~m}$ in the north-eastern part of the Valley. This is the most active area in terms of geodynamic and seismic activities, with daily rockfall events and numerous catastrophic floods recorded in the past centuries, thus presenting the area with expressed landslide and flood hazard. Types of movements that can be distinguished in this area include debris avalanches over the flysch bedrock, rockfalls from limestone cliffs, sliding of

\footnotetext{
* Correspondence: sanja.dugonjic@uniri.hr

University of Rijeka, Faculty of Civil Engineering, Rijeka, Croatia
}

huge mega blocks and rocky towers, complex active, dormant and reactivated translational landslides on both sides of the Valley (Benac et al. 2009).

The kinematics of the structural elements in the central part of the Rječina Valley are based on the relationship between relatively rigid carbonate rocks and ductile siliciclastic rocks during simultaneous deformations (Fig. 1).The Valley is a part of a dominant morphostructural unit that strikes in the northwest-southeast direction (Ilirska Bistrica-Klana-Rječina Valley-Bakar Bay-Vinodol Valley). Paleogene siliciclastic sedimentary rocks, i.e. flysch (sandstones, siltstones and marls in alteration) have a form of a squeezed synciline between karstified carbonate rocks (Upper Cretaceous and Paleogene limestone) which prevail in a wide area of the mentioned morphostructural unit (Velić and Vlahović 


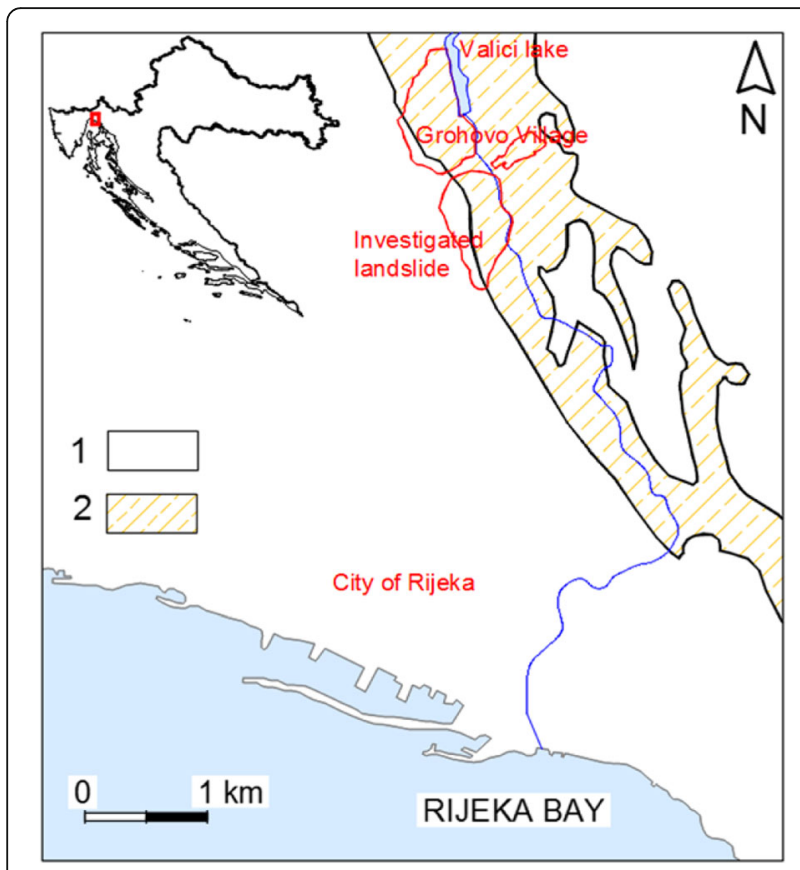

Fig. 1 Position of the investigated area on the simplified geological map of the central and lower part of the Rječina Valley (according: Velić and Vlahović 2009):1-karstified carbonate rocks, 2- siliciclastic sedimentary rocks

2009). Geological contacts between carbonate and flysch rock mass are reverse faults, with different mechanisms of origin. Neotectonic and recent tectonic movements have caused irregular subsidence of flysch areas and the uplifting of the surrounding karstic terrain, whereupon karstified limestone rock masses are visible on the top of the slopes and the flysch rock mass can be found in the bottom of the Valley.

The siliciclastic flysch bedrock is characterized by a significant lithological heterogeneity, because of a frequent vertical and lateral alternation of different lithological sequences. Flysch rock mass is more subject to weathering, forming a clayey weathering zone, which mixed with the coarse grained rock fragments forms few meter-thick unstable slope deposits.

Historical descriptions from the Croatian State Archive in Rijeka (Anon 2011a, 2011b), present many evidences of landslides occurrences triggered by rainfall, floods or earthquakes, recorded in the Rječina River Valley during 19th and 20th century (Fig. 2). The last major complex retrogressive landslide with volume of approximately $3.0 \times 10^{6} \mathrm{~m}^{3}$ was reactivated in December 1996 (Fig. 2c) near Grohovo Village on the NE slope. Valići landslide (Fig. 2b), as the most recent of large landslides in the area, activated in February 2014 on SW slope, due to long period of heavy rainfall, and moved $1.0 \times 10^{6} \mathrm{~m}^{3}$ of sliding mass to the reservoir(Arbanas et al. 2014). The NE slope is monitored since 1998 (including 22 benchmarks, inclinometers, deformeters and piezometers) and further on from 2011 (including geodetic surveys of 25 benchmarks observed by robotic total station, measurements from 9 GPS receivers, vertical inclinometers and extensometers, long span and short span horizontal extensometers, pore pressure gauges and rain gauge). Landslide inventory of the Valley was determined using airborne LiDAR imagery scanned in March 2012 (Arbanas et al. 2014).

This paper presents an investigation of the dormant landslide located on the SW slope of the Valley

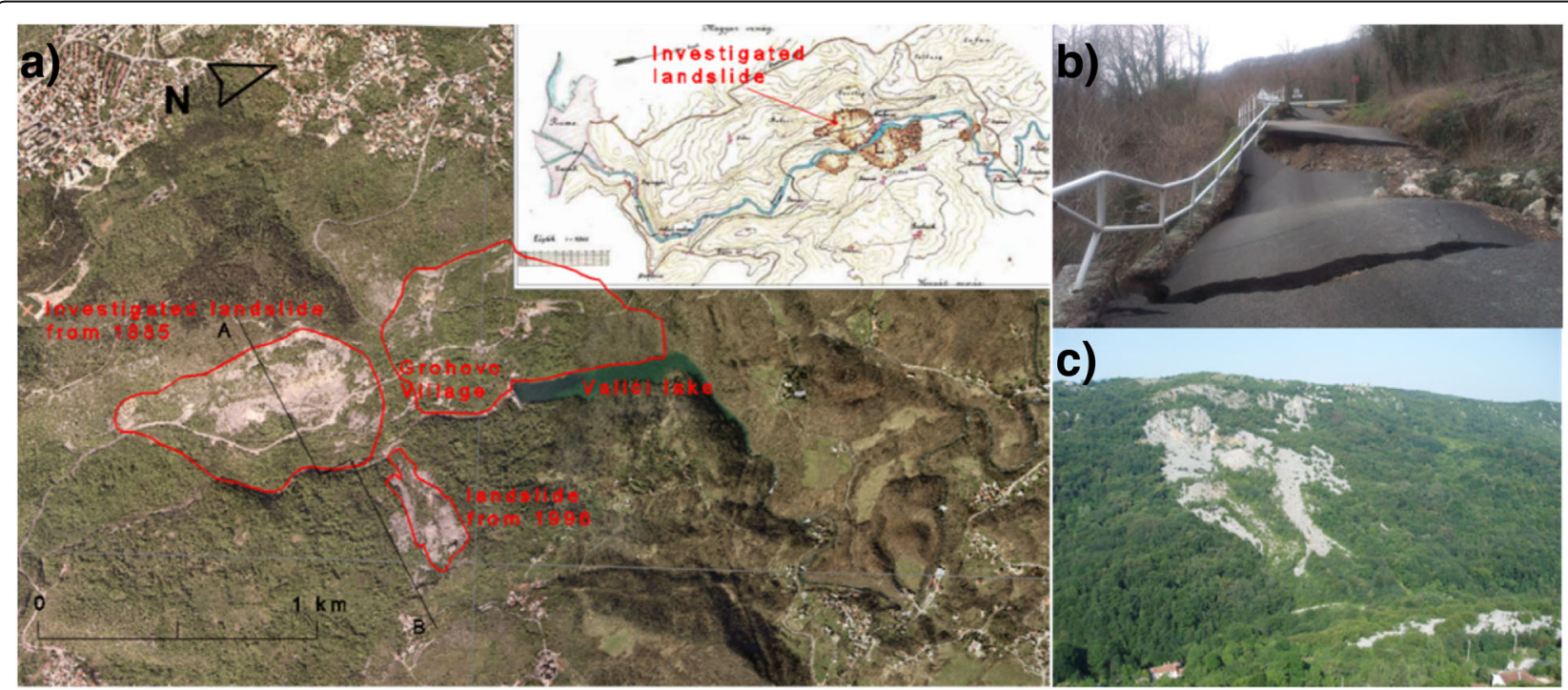

Fig. 2 View of the investigated landslide and the most recent large instabilities: a) position on the orto photomap from 2008 and on the topographic map from 1894 (Anon, 2011 b); b) Valići landslide from 2014; c) Grohovo landslide from 1996 
(Fig. 2a).The parameters of the slope materials, the thickness of the slope deposits, the position of the flysch bedrock and the sliding surface are well known on the NE slope due to long term investigation of the Grohovo landslide (from 1996). On the other hand, on the investigated SW slope there are no data from any past investigation works. The first described record of sliding on this location, dates back from1767 (Lopacsaer Plan Idealis), describing numerous landslide and rockfall events caused by the 1750 earthquake (intensity 9 according MercalliCancani-Sieberg scale). Later on, in 1870 when a destructive earthquake struck the broader area of the City of Rijeka, a huge rock avalanche was recorded at the same location on SW slope. Landslide reactivation was triggered again in 1885 by the intense and long-term rainfall, when the sliding mass has destroyed or damaged most of the houses in the Grohovo Village area on the right river bank.

The present topography of the investigated landslide shows clear landslide features that can be easily compared to the topographic map from 1894 (Fig. 2a). The crown and the main scarp are characterized by steep, 10 to $40 \mathrm{~m}$ high limestone cliffs (Fig. 3c). The total length of tensile crack is around $800 \mathrm{~m}$. Debris deposits are present over the flysch bedrock, over the whole depletion zone. Fresh marks of debris avalanche in the upper part of the landslide body can be often seen (Fig. 3b). Limestone blocks, visible on the top of the depleted mass, around $30 \mathrm{~m}$ from the main scarp, evidence their translation and rotation in the past sliding processes. Accumulation zone is spreading over and beneath the county road that is passing through the displaced landslide mass (Fig. 3a).Estimated dimensions of the landslide from 1885are $\mathrm{L}=545 \mathrm{~m} ; \mathrm{L}_{\mathrm{d}}=530 \mathrm{~m} ; \mathrm{L}_{\mathrm{r}}=430 \mathrm{~m}$; $\mathrm{W}_{\mathrm{d}}=970 \mathrm{~m} ; \mathrm{W}_{\mathrm{r}}=705 \mathrm{~m}$. To investigate the possibility of the landslide reactivation under certain conditions, a 2D back stability analysis was performed based on the rock mass strength parameters obtained from laboratory testing in order to determine the landslide dimensions and to define the approximate position of the sliding surface. The data about the present slope topography was provided by the Remotely Piloted Aircraft System (RPAS), using Structure-from-Motion (SfM) photogrammetry to derive 3D point cloud.

The use of RPAS presents a new revolution in geodetic profession, and has a great potential in the field of natural hazard phenomena, since it is becoming a powerful tool in alternative to the traditional monitoring and surveying systems in order to reproduce $3 \mathrm{D}$ models, highresolution images and maps. The main advantages are low costs, usage in hard reachable areas with low risk for operators doing the survey and repeatability of flights allowing a multi-temporal analysis, operated by one person. Due to progressive development, but also some illegal applications, violation of personal data, political incidents and other bad examples of their application, there are more and more legislative limitations around the world. They should be respected according to different international (Authority of International Civil Aviation Organization), regional (European Aviation Safety Agency authority) and national (here Croatian Civil Aviation Agency authority) legislation. There is a small
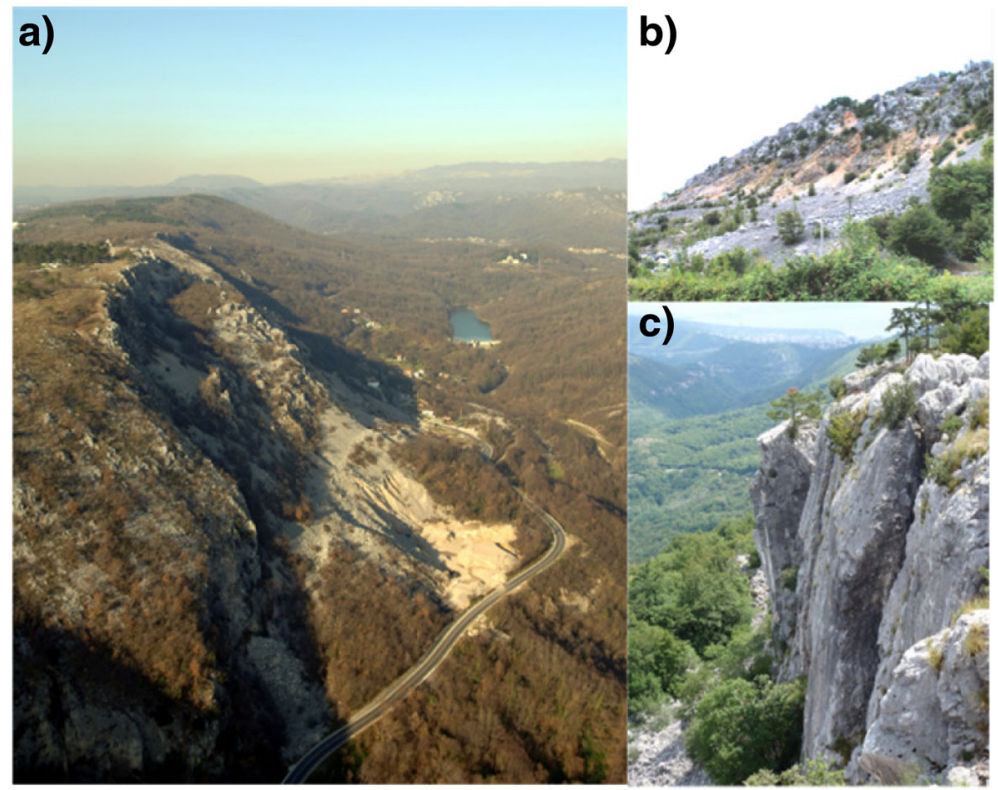

Fig. 3 Investigated landslide on the SW slope: a ) aerial view of the landslide; b) fresh marks of debris avalanche in the upper part of the landslide body; c) limestone cliff as a part of the landslide main scarp above the depletion zone 


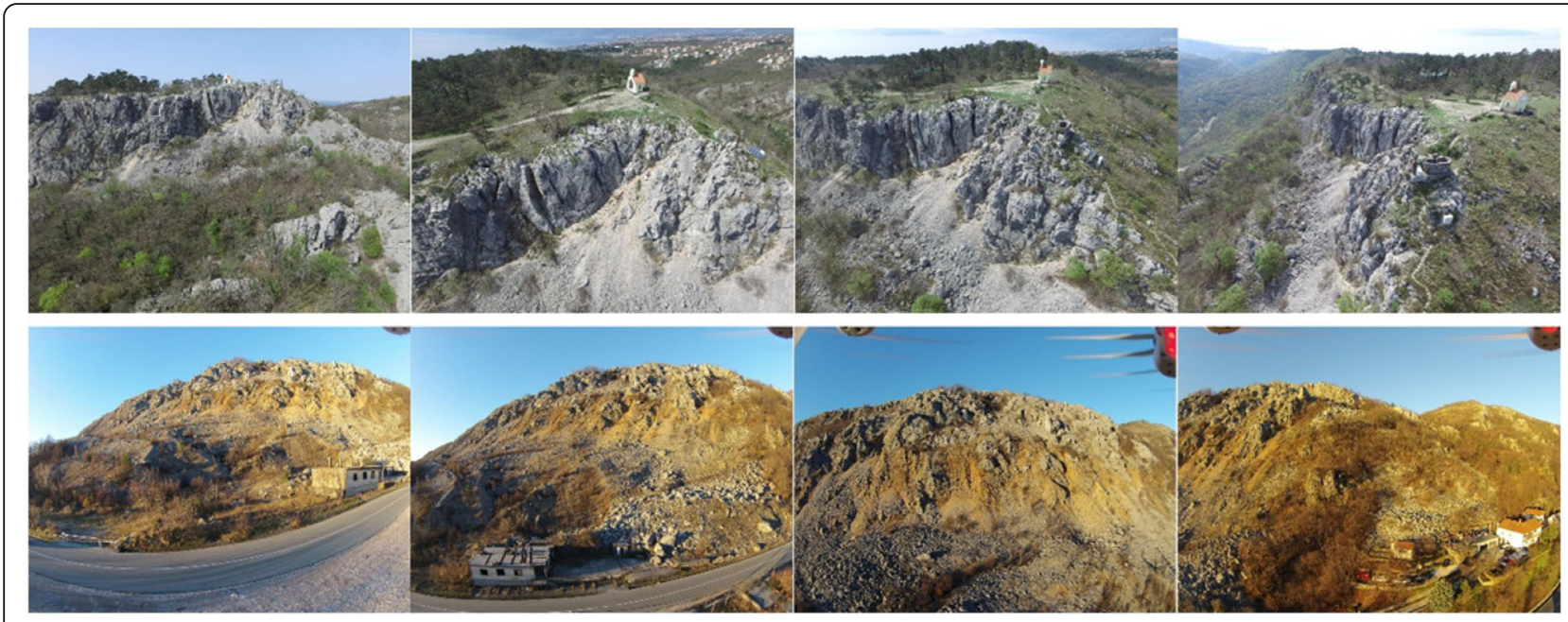

Fig. 4 Photos taken from RPAS (upper row-landslide crown view; lower row- view of the landslide body)

number of publications describing methodology of application on different case studies, from landslide phenomena (Niethammer et al. 2012, Car et al., 2016), erosion processes (D'Oleire-Oltmanns et al. 2012, Ružić et al. 2013), geomorphological mapping (Hugenholtz et al. 2013) but also coastal engineering and beach topography changes (Hapke and Richmond 2000, Mancini et al. 2013, Ružić et al. 2015, Casella et al. 2016), hydrological context, inspection of various structures (Jurić Kaćunić et al. 2016), vegetation monitoring (Berni et al. 2009), ecology (Anderson and Gaston 2013) etc., although they are increasingly used and valuable for further researches.

As from described historical events can be seen, the main triggers of instabilities in the area are rainfall and earthquakes. According to the Republic of Croatia seismicity map (http://seizkarta.gfz.hr/), which was derived from the data base of more than 40000 earthquakes in the Republic of Croatia and neighbouring areas, peak ground acceleration of the ground for the return period of 95 years is $\mathrm{a}=0.1 \mathrm{~g}$ and for the return

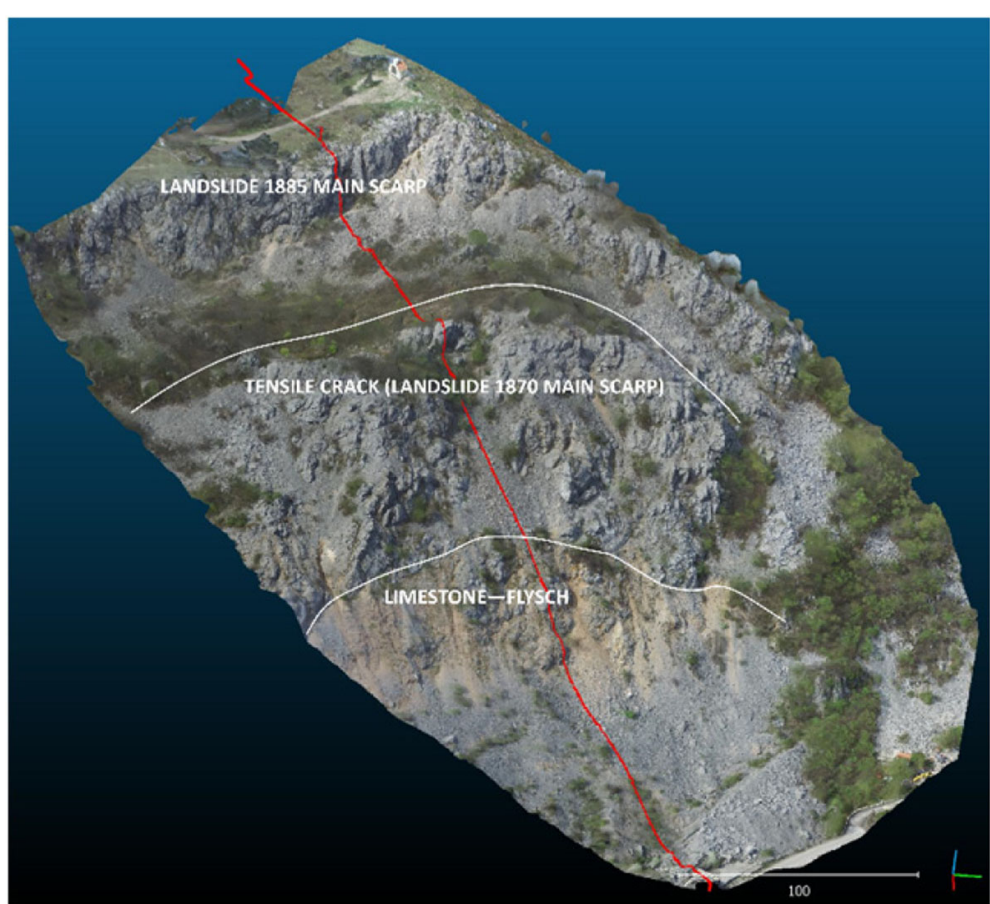

Fig. 5 Digital terrain model derived from the RAPS and SfM application (red polyline shows the analysed cross-section position) 


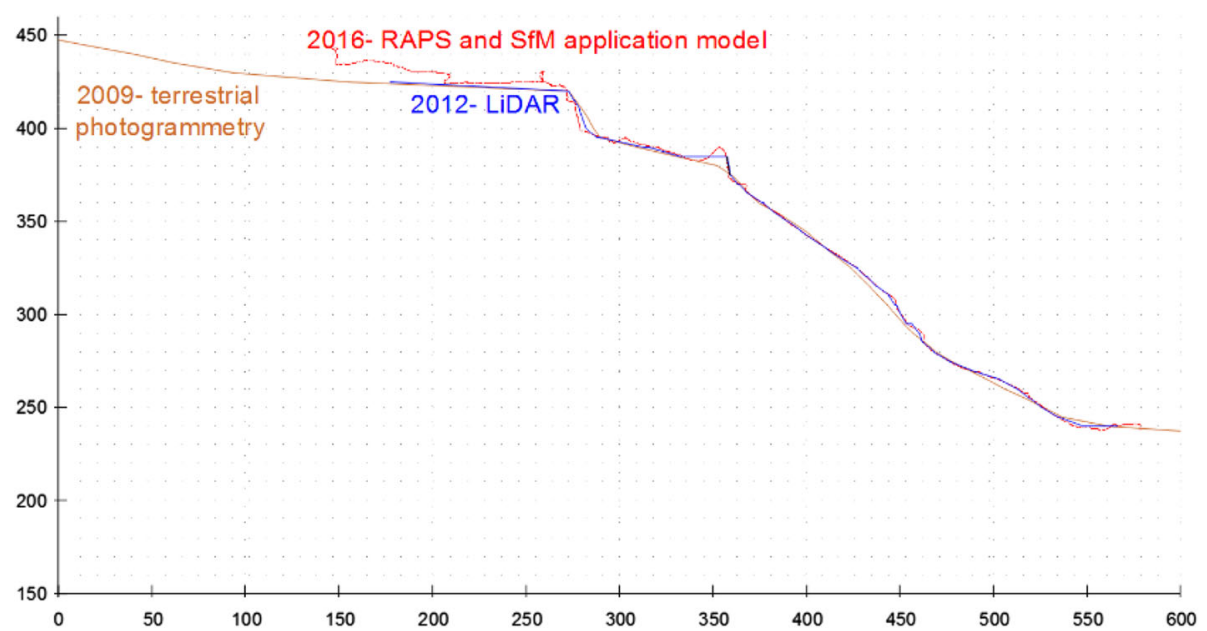

Fig. 6 Cross-section of the SW slope in the Rječina River Valley recorded using different methodology from 2009 to 2016

period of 475 years $\mathrm{a}=0.22 \mathrm{~g}$ (where $\mathrm{g}=9.81 \mathrm{~m} / \mathrm{s}^{2}$ ). Seismic hazard was calculated using Monte-Carlo method, where probability to exceed specific acceleration value was defined from statistical analysis of earthquake catalogue generated using the empirical distribution (AR2) for each mesh element and a very long period (more than 2000000 of years).Limit equilibrium stability analysis of the present SW slope conditions, were performed for the possible seismic scenarios.

\section{Methods}

Topographical data of the Rječina River Valley have been recorded in several occasions: in 2009 using terrestrial photogrammetry method (for the purposes of topographical map creation) and in 2012usingairborne LiDAR (airborne laser scanning- ALS) when the area was one of the pilot areas in a Croatian-Japanese join research project. To provide the data about the present slope topography and to give the first insight into the steep, hard accessible and superficially unstable SW slope on the right river bank, Grohovo landslide (1870 and 1885) area was recorded using Consumer-grade DJI Phantom 2 RPAS owned by the Faculty of Civil Engineering in Rijeka (Fig. 4).

A Structure-from-Motion (SfM) photogrammetric method was used to obtain parameters such as the area of the cliff-overhang material, the height of the cliff face and the length of the notch (Ružić et al. 2014). These are derived from geo-referenced 3D point clouds generated from approximately 200 images using the Autodesk ReCap online service (https://recap360.autodesk.com/). The images were collected using a single 10-megapixel Ricoh GR Digital IV camera equipped with a high-

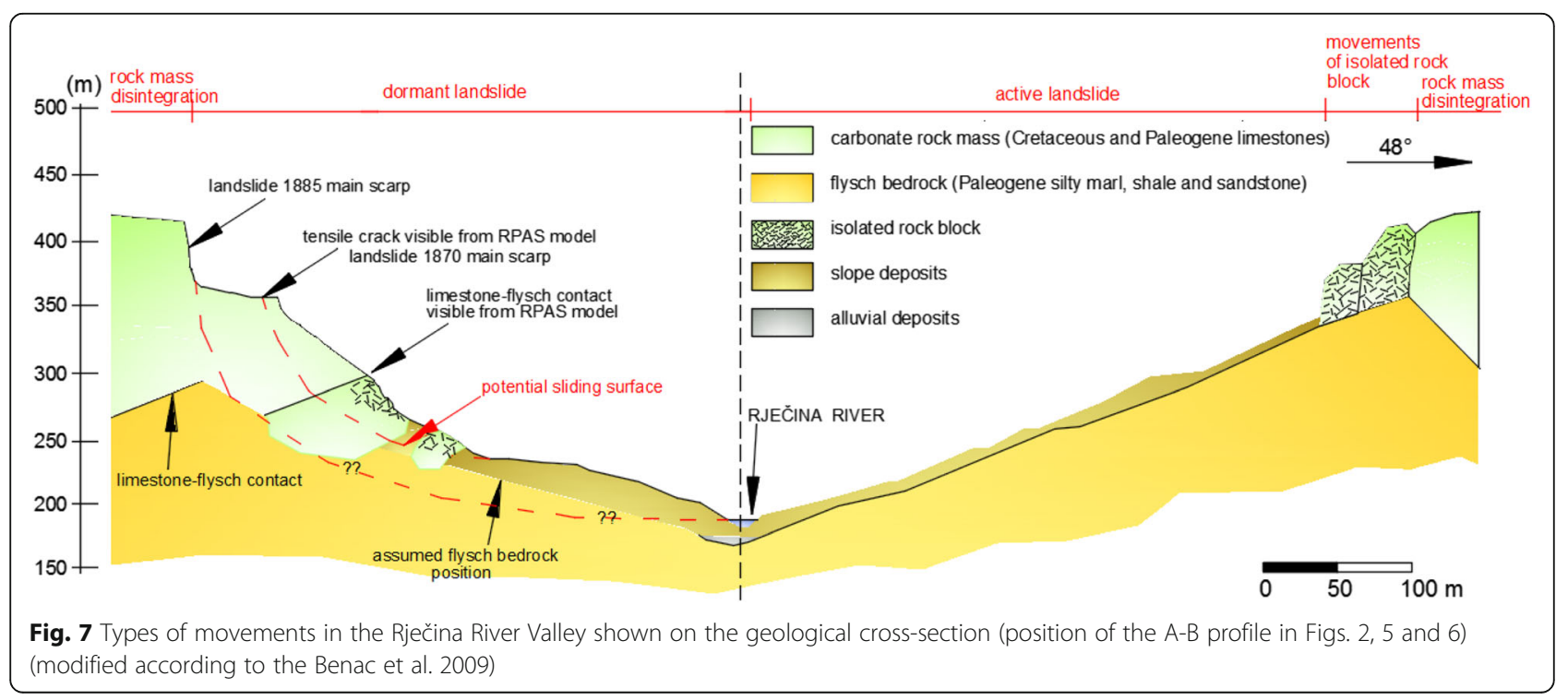




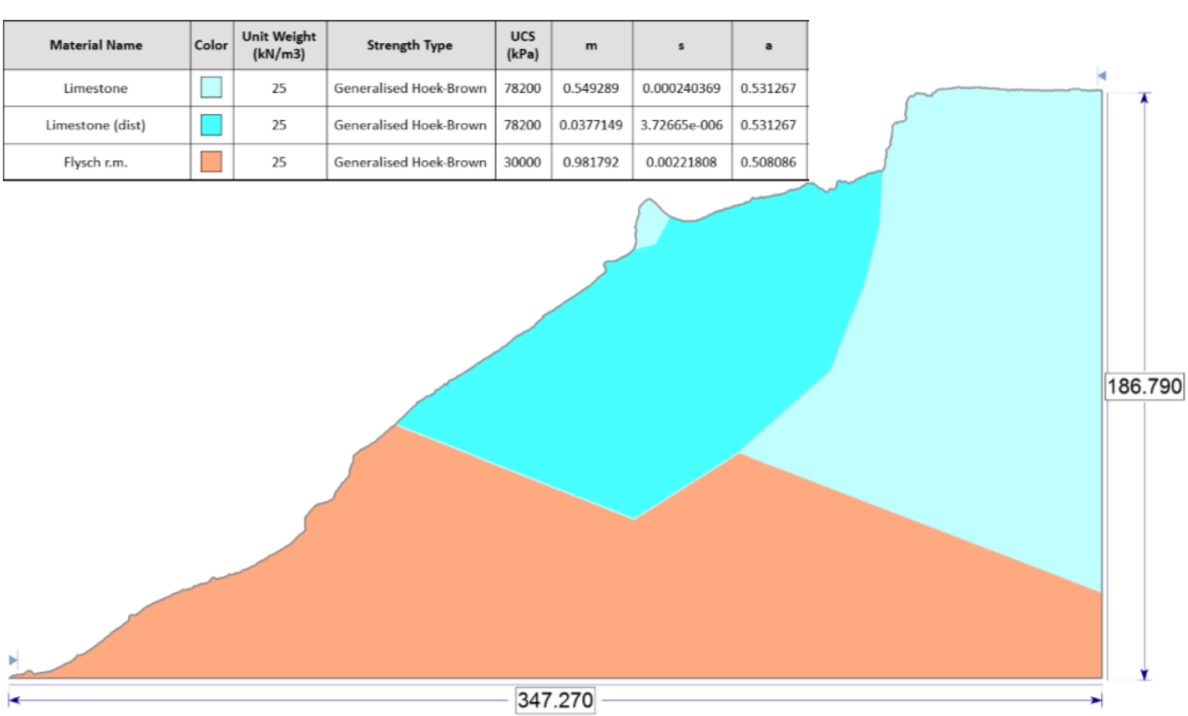

Fig. 8 Material characteristics and geometry of the numerical model

contrast 6-mm f/1.9 GR lens. Special care was needed to acquire sharp and well-focused images from different locations covering a range of vertical and horizontal angles. It is important to point out that all the images were taken within a period of less than two hours. Complete field measurements, including RTK-GPS surveys, took about six hours for a two-person team. Visual checks were used to select images to upload to the Autodesk ReCap online service and for 3D point cloud verification, as suggested by Podobnikar (2009). Cloud Compare software (http:// www.danielgm.net/cc/) was used for the point cloud georeferencing. A small number of ground-control points (GCPs) were measured in the field using Real Time Kinematic GPS (RTK-GPS) after the images were taken. These were then used for the transformation of coordinates from a relative to the absolute coordinate system (e.g. Westoby et al. 2012).

Few limestone blocks were taken from the landslide surface and cylindrical test specimens were prepared for uniaxial testing according to the ASTM D 4543-08. Uniaxial tests were performed in the Geotechnical laboratory of the Faculty of civil engineering, University of Rijeka, using FORM + TESTs ALPHA 1-2000s uniaxial compression testing machine, according to ASTM D7012-10.Uniaxial compressive strength values obtained from the uniaxial testing ranged from $73 \mathrm{MPa}$ up to $96 \mathrm{MPa}$. Rock mass strength was estimated using the generalized Hoek-Brown failure criterion. Taking into account the effects from previous instabilities which have probably caused significant disturbance of the rock mass in the deposition zone, a

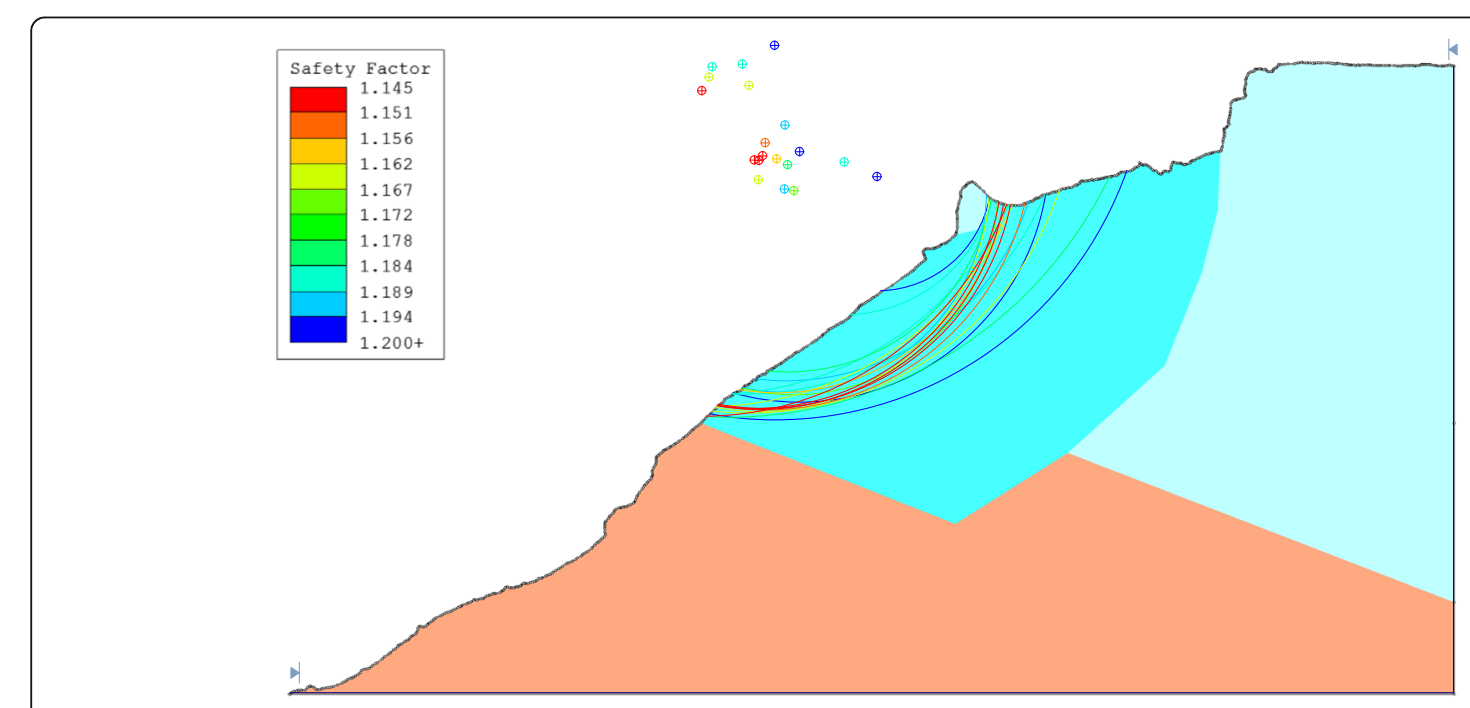

Fig. 9 Stability back analysis (Spencer's method) showing $F_{S, \min }=1.146$ 


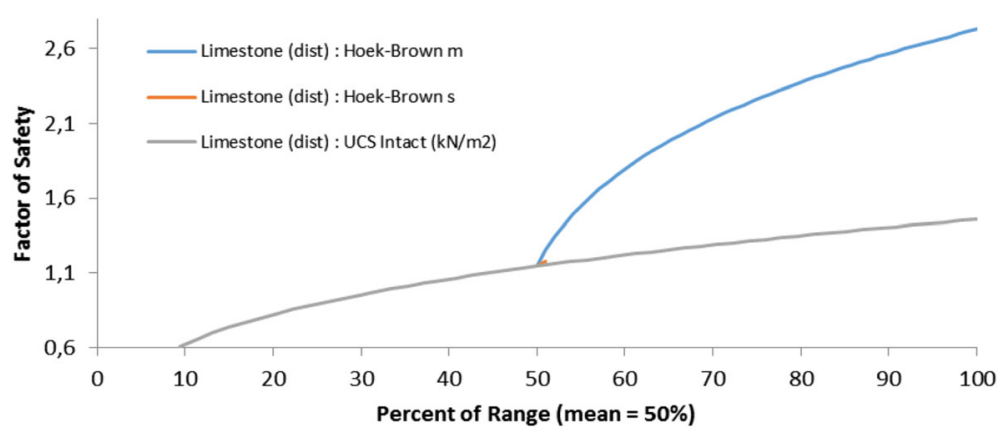

Fig. 10 Sensitivity plot for different values of disturbance factor $D$ and UCSi

disturbance factor (D) of 1 was adopted in this zone. Adopting the mean value of Uniaxial Compressive Strength for intact rock (UCSi) of 78.2 $\mathrm{MPa}$, unit weight of $26 \mathrm{kN} / \mathrm{m}^{3}$, RMR value of 30 and intact rock constant mi equal to 8 , a limit equilibrium analysis was performed in order to estimate the stability for the derived profile (Fig. 8). All stability analyses were performed using the software Rocscience, Slide, Version 7.009 (Rocscience Inc. Toronto, Canada) and Spencer's calculation method for the profile recorded in 2016 (using RAPS and SfM application). The depth of the sliding surface and the position of the flysch bedrock are assumed based on the landslide geometry. Vegetation bumps on the profile have been removed before further stability analysis.

\section{Results and Discussion}

As it can be seen on Fig. 5, the RAPS and SfM application produced high accuracy landslide 3D point cloud, characterized by safe and quick data acquisition. Georeferenced landslide point cloud delivered from images was compared with data acquired from ALS (DEM derived in the post processing form the ALS was $1 \mathrm{~m}$ resolution) at the same profile position (Fig. 6). Good accordance and small changes in the profile topography can be evidenced through the years.

Some landslide features visible from the landslide topography and shown on the simplified geological cross section in Fig. 7, crucial for the sliding surface reconstruction, are evidenced on the new topographical model derived using SfM photogrammetric method (Fig. 5). Right side of Fig. 7 shows typical movements and the geological cross-section on the NE slope, known from the numerous past investigation works. On the left side of Fig. 7 marks of main landslide scarps (from 1870 and 1885) together with the position of the flysch-limestone contact, visible from RPAS model, are shown. The superficial contact point between flysch and limestone was acquired from the point cloud data and the contact plane orientation was assumed in the model. Preliminary stability analysis which involves facts about landslide features, but also some assumptions elaborated in Fig. 7, presents reconstruction of the past landslide mechanisms, and provides the present potential sliding surface in further stability analyses results. Since there is a great uncertainty about the deeper sliding surface extent and position, as part of the landslide body was removed after the landslide occurred, and the topography was thereby changed, only

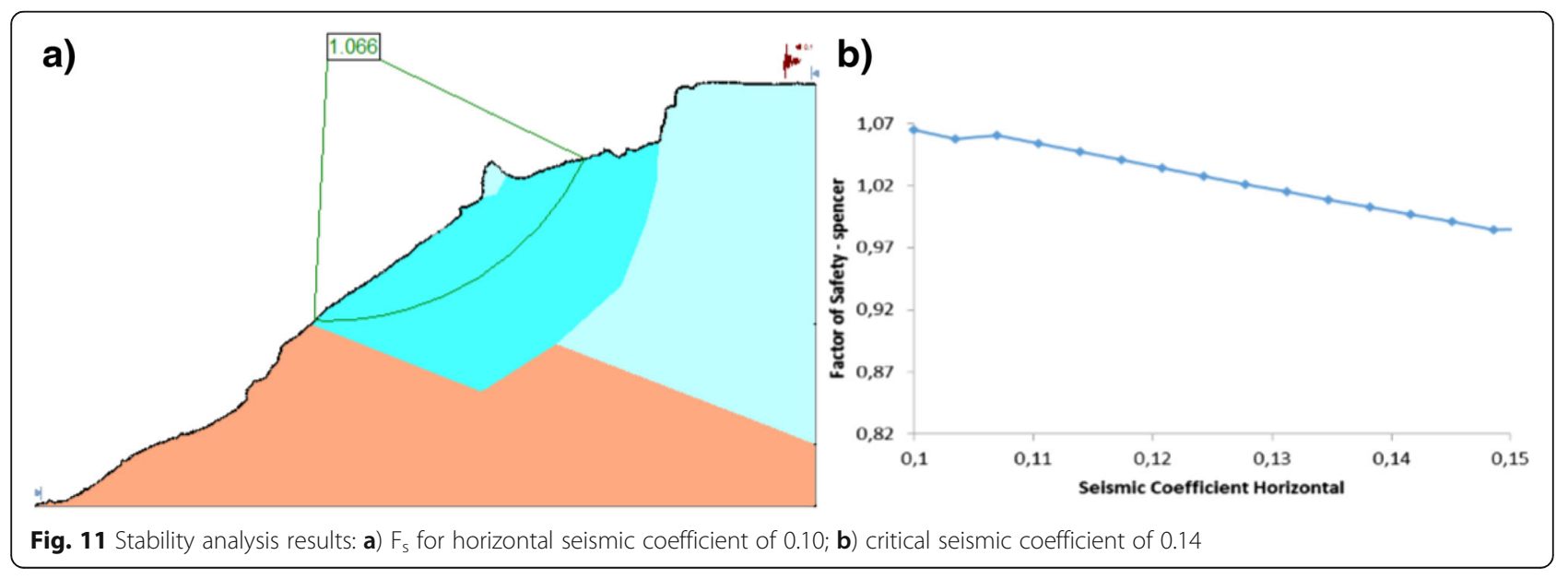


the shallow landslide that can be correlated with the landslide from 1870 position, could be analysed. Main features of numerical model used in the stability analyses are shown in Fig. 8.

Stability analyses results show that the slope is marginally stable for dry conditions with the factor of safety below 1.15 (Fig. 9). Although there are many elaborated uncertainties included in this calculation (including strength parameters for the flysch rock mass), preliminary results show failure surfaces with the lowest safety factor values around the location of the critical one shown in Fig. 7.

Sensitivity analysis was performed in order to assess the impact of the possible deviations for some of the parameters used in the numerical model. Mean, minimum and maximum values for selected material properties were defined and a strength criterion was adjusted in order to fit these conditions. Value of the disturbance factor $D$ ranges from 0.8 to 1 , while Uniaxial Compressive Strength of intact limestone rock varies from 65 to $80 \mathrm{MPa}$. Results of the performed sensitivity analysis and change in the safety factor for selected variables are shown in Fig. 10. Results show that even small reduction of disturbance factor generates high increase in the factor of safety. For value $D=0.9$ calculated factor of safety is around 2.23.

Figure 11 shows the results of the seismic scenario calculation, defined using the pseudo static approach, with horizontal seismic load coefficient of 0.1 and seismic force orientated down slope. As it can be seen, taking into account completely dry conditions on the slope, resulting seismic force would cause reduction of the safety factor close to the value 1 (Fig. 11a). In order to explore the maximum earthquake acceleration in horizontal direction that would trigger the instability, critical seismic coefficient was calculated using the sensitivity option, as well. Fig. 11b shows that the critical seismic coefficient of about 0.14 is limiting value for which generated inertial forces correspond to the factor of safety equal to 1 .

\section{Conclusions}

Many activities were initiated through different investigation periods, focusing on reduction of the possible landslide hazard in the Rječina River Valley, near City of Rijeka, in Croatia, where numerous instability phenomena, in the past two centuries, have been recorded. 2D stability back analyses were performed on the SW slope of a dormant landslide, in the Rječina River Valley, with the purpose to predict the possible reactivation, on the basis of landslide features present on the field. Unknown and steep topography of the slope, covered by unstable debris material, imposed the usage of a Remotely Piloted Aircraft System (RPAS) to provide the data about the present slope topography. The landslide 3D point cloud was derived using Structure-from-Motion (SfM) photogrammetry, and to verify the cloud of georeferenced sliding points delivered from images, it was compared with the existing models acquired from terrestrial photogrammetry and laser scanning in the Valley from 2012.In general, it can be noticed that drones are closing the gaps in small scale remote sensing, as they allow the acquisition of topographic data at low cost and possibly repeated survey in short period. The comparison of the digital elevation model recorded with LiDAR imaginary, RAPS and SfM application, shows good accordance what evidences that RPAS and photogrammetry as low-cost and high-resolution are efficient tools, which can be employed effectively to record changes of landslide topography through time.

Since earthquakes are one of the main triggers of instabilities in the area, stability analysis of the present slope conditions, were performed for possible seismic scenarios. Stability analysis results have shown that the slope is marginally stable for dry conditions. The results show failure surfaces with the lowest values of safety factors near the location of the critical one. Advanced seismic analyses have shown that limiting value of the critical seismic coefficient 0.14 could trigger the landslide.

\section{Acknowledgements \\ This work has been supported in part by Ministry of Science, Education and Sports of the Republic of Croatia under the project Research Infrastructure for Campus-based Laboratories at the University of Rijeka, number RC.2.2.06-0001. The project was co-funded from the European Fund for Regional Development (ERDF). We would also like to acknowledge the University of Rijeka for support in the research projects "Geological hazard in the Kvarner area" and "Development of the landslide monitoring and early warning system for the purpose of landslide hazard mitigation" and Duje Kalajžić for technical support in RPAS piloting.}

\section{Authors' contributions}

SDJ has made the paper's concept, giving the introduction part and presenting the research problem and methodology, she has contributed in the laboratory work, field data acquisition and interpretation of the results, as well as making the final conclusions and general supervision. JP has contributed in the laboratory testing and field data acquisition, has performed stability analyses presented in the paper and has been involved in results interpretation. IR has operated the Remotely Piloted Aircraft System (RPAS) and has derived 3D point cloud using SFM photogrammetry. ŽA has been involved in revising the interpretation of the presented geotechnical profile and the final approval of the paper's concept. All authors read and approved the final manuscript.

\section{Competing interests}

The authors declare that they have no competing interests.

Received: 15 October 2016 Accepted: 23 November 2016

Published online: 01 December 2016

\section{References}

Anderson, K., and K.J. Gaston. 2013. Lightweight unmanned aerial vehicles will revolutionize spatial ecology. Frontiers in Ecology and the Environment 11: 138-146. doi:10.1890/120150.

Anon (2011a), Croatian State Archive in Rijeka: Civil engineering bureau district Sušak, fond JU 49, box 13: Rivers and streams regulation.

Anon (2011b), Croatian State Archive in Rijeka: Technical bureau of the City of Rijeka, fond JU 51, box 45: Rječina river regulation. 
Arbanas, Ž., S. Mihalić Arbanas, M. Vivoda, J. Peranić, S. Dugonjić Jovančević, and V. Jagodnik. 2014. Identification, monitoring and simulation of landslides in the Rječina River Valley, Croatia. In Proceedings of the SATREPS Workshop on Landslide Risk Assessment Technology, Sassa, Kyoj, ed. Q. Dang Khang, 200-213. Kyoto: International Consortium on Landslides.

Benac Č, Dugonjić S, Arbanas Ž, Oštrić M, Jurak V (2009) The Origin Of Instability Phenomena Along The Karst-Flysch Contacts, ISRM International Symposium EUROCK 2009: Rock engineering in difficult ground conditions soft rock and karst (Vrkljan I, ed.), 29 - 31th October, Cavtat, Croatia, CRC Press, 757-761. https://www.crcpress.com/Rock-Engineering-in-Difficult-Ground-ConditionsSoft-Rocks-and-Karst/Nrkljan/p/book/9780415804813.

Berni, J.A.J., P.J. Zarco-Tejada, L. Suárez, and E. Fereres. 2009. Thermal and narrowband multispectral remote sensing for vegetation monitoring from an unmanned aerial vehicle. IEEE Transactions on Geoscience and Remote Sensing 47: $722-738$

Car M, Jurić Kaćunić D, Kovačević MS (2016) Application of Unmanned Aerial Vehicle for Landslide Mapping, Proceedings of the International Symposiun on Engineering Geodesy - SIG 2016 / Paar R, Marendić A, Zrinjski M. (eds.), 20th-22nd May 2016, Varaždin, Croatia, Croatian Geodetic Society, 549-559.

Casella, E., A. Rovere, A. Pedroncini, C.P. Stark, M. Casella, M. Ferrari, and M. Firpo. 2016. Drones as tools for monitoring beach topography changes in the Ligurian Sea (NW Mediterranean). Geo-Marine Letters 36(2): 151-163.

D'Oleire-Oltmanns S, Marzolff I, Peter KD, Ries JB (2012) Unmanned Aerial Vehicle (UAV) for Monitoring Soil Erosion in Morocco, Remote Sensing 2012, 4, 3390-3416; doi: 10.3390/rs4113390, pp 3390-3416.

Hapke, C., and B. Richmond. 2000. Monitoring beach morphology changes using small-format aerial photography and digital softcopy photogrammetry. Environmental Geosciences 7: 32-37.

Hugenholtz, C.H., K. Whitehead, O.W. Brown, T.E. Barchyn, B.J. Moorman, A. LeClair, K. Riddell, and T. Hamilton. 2013. Geomorphological mapping with a small unmanned aircraft system (sUAS): feature detection and accuracy assessment of a photogrammetrically-derived digital terrain model. Geomorphology 194: 16-24.

Jurić Kaćunić D, Librić L, Car M (2016) Application of unmanned aerial vehicles on transport infrastructure network, Građevinar 68(2016)4, doi: 10.14256/JCE. 1382.2015, 287-300

Mancini, F. M. Dubbini, M. Gattelli, F. Stecchi, S. Fabbri, and G. Gabbianelli. 2013. Using unmanned aerial vehicles (UAV) for high-resolution reconstruction of topography: the structure from motion approach on coastal environments. Remote Sensing 5(12): 6880-6898. doi:10.3390/rs5126880

Niethammer, U., M.R. James, S. Rothmund, J. Travelletti, and M. Joswig. 2012. UAV-based remote sensing of the Super Sauze landslide: evaluation and results. Engineering Geology 128: 2-11.

Podobnikar T (2009) Methods for visual quality assessment of a digital terrain model. S.A.P.I.EN.S [Online], 2, 2. http://sapiens.revues.org/738. Accessed 4 Apr 2014.

Ružić, I., I. Marović, M. Vivoda, S. Dugonjić Jovančević, D. Kalajžić, Č. Benac and N. Ožanić 2013. Application of Structure-from-Motion photogrammetry for erosion processes monitoring, Moscenicka Draga example, Proc. of the 4th Workshop of the Japanese-Croatian Project on "Risk Identification and Land-Use Planning for Disaster Mitigation of Landslides and Floods in Croatia, 49-50. Split: University of Split.

Ružić I, Marović I, Benac Č, llić S (2014) Coastal cliff geometry derived from structure-from motion photogrammetry at Stara Baška, Krk Island, Croatia. Geo-Marine Letters. doi 10.1007/s00367-014-0380-4

Ružić, l., Č. Benac, I. Marović, and S. Ilić. 2015. A stability assessment of coastal cliffs using digital imagery. Acta Geotechnica Slovenica 2015(2): 25-35.

Velić I, Vlahović I (2009) Geološka karta Republike Hrvatske 1:300.000 (Geological map of the Republic of Croatia 1:300.000). Croatian Geological Survey, Zagreb. (in Croatian)

Westoby, M.J. J. Brasington, N.F. Glasser, M.J. Hambrey, and J.M. Reynolds. 2012. "Structure-from-Motion" photogrammetry: A low-cost, effective tool for geosciences applications. Geomorphology 179: 300-314.

\section{Submit your manuscript to a SpringerOpen ${ }^{\odot}$ journal and benefit from:}

- Convenient online submission

- Rigorous peer review

- Immediate publication on acceptance

- Open access: articles freely available online

- High visibility within the field

- Retaining the copyright to your article

Submit your next manuscript at $\gg$ springeropen.com 